\title{
Influence of Thiourea Concentration on Some Physical Properties of Chemically Sprayed $\mathrm{Cu}_{2} \mathrm{ZnSnS}_{4}$ Thin Films
}

\author{
Nabeel A. Bakr*, Ziad T. Khodair, Hussein I. Mahdi \\ Department of Physics, College of Science, University of Diyala, Diyala, Iraq \\ Email address: \\ nabeelalibakr@yahoo.com (N. A. Bakr), nabeelalibakr@sciences.uodiyala.edu.iq (N. A. Bakr) \\ ${ }^{*}$ Corresponding author
}

\section{To cite this article:}

Nabeel A. Bakr, Ziad T. Khodair, Hussein I. Mahdi. Influence of Thiourea Concentration on Some Physical Properties of Chemically Sprayed $\mathrm{Cu}_{2} \mathrm{ZnSnS}_{4}$ Thin Films. International Journal of Materials Science and Applications. Vol. 5, No. 6, 2016, pp. $261-270$. doi: 10.11648/j.ijmsa.20160506.15

Received: September 28, 2016; Accepted: October 7, 2016; Published: November 1, 2016

\begin{abstract}
In this work $\mathrm{Cu}_{2} \mathrm{ZnSnS}_{4}$ (CZTS) films were deposited by using chemical spray pyrolysis (CSP) technique at substrate temperature of $(400 \pm 10){ }^{\circ} \mathrm{C}$ and thickness of about $(300 \pm 10) \mathrm{nm}$ at different Thiourea Concentrations of $(0.14$, $0.16,0.18,0.20,0.22$ and 0.24$) \mathrm{M}$. Copper chloride $(\mathrm{CuCl})$, zinc chloride $\left(\mathrm{ZnCl}_{2}\right)$, tin chloride $\left(\mathrm{SnCl}_{4} .5 \mathrm{H}_{2} \mathrm{O}\right)$ and thiourea $\left(\mathrm{SC}\left(\mathrm{NH}_{2}\right)_{2}\right)$ were used as sources of copper ions, zinc ions, tin ions and sulfur ions respectively. The structural, morphological and optical properties of these films have been studied using XRD, AFM, and UV-Visible spectroscopy respectively. The XRD results showed that all films are polycrystalline in nature with tetragonal structure and preferred orientation along (112) plane. The crystallite size $\left(\mathrm{D}_{\mathrm{av}}\right)$ of all samples was calculated using Scherrer's equation and it is found that the sample deposited at thiourea concentration of $0.20 \mathrm{M}$ has maximum crystallite size of $31.25 \mathrm{~nm}$, while it was minimum $(18.02 \mathrm{~nm})$ for the sample prepared at thiourea concentration of $0.16 \mathrm{M}$. The AFM results showed smooth and homogenous thin films. The optical energy band gap $\left(E_{g}\right)$ for allowed direct electronic transition was calculated using Tauc's plot. It is found that the energy band gap $\left(E_{g}\right)$ decreases as the thiourea concentration increases and it was in the range of $(2.22-1.75) \mathrm{eV}$. Urbach energy, refractive index, extinction coefficient and dielectric coefficient of all deposited films were estimated and the results were discussed.
\end{abstract}

Keywords: CZTS Thin Films, Thiourea Concentration, Chemical Spray Pyrolysis, XRD, Optical Properties

\section{Introduction}

$\mathrm{Cu}_{2} \mathrm{ZnSnS}_{4} \quad$ (CZTS) compound, which consists of abundant materials, is one of the promising materials for lowcost thin film solar cells. In fact, it exhibits a suitable bandgap energy of $(1.4-1.5) \mathrm{eV}$, and large absorption coefficient higher than $10^{4} \mathrm{~cm}^{-1}[1,2]$.

In addition, the compound can find wide practical applications in the production of broadband optical converters, detectors of radiation in the near-infrared optical region, and other microelectronic and nano electronic devices. Using $\mathrm{Cu}_{2} \mathrm{ZnSnS}_{4}$ (CZTS) compound, solar cells have been produced with an efficiency of higher than $11 \%$ [3].

Chemical Spray pyrolysis (CSP) is a versatile technique that has been used before for the deposition of thin films of many types of compounds [4]. Moreover, it is cost effective, it does not require high vacuum, it can be used for irregular geometries and it can be used even on top of flexible substrates. Chemical Spray pyrolysis of $\mathrm{Cu}_{2} \mathrm{ZnSnS}_{4}$ (CZTS) thin films was first reported by Nakayama and Ito [5]. In this study, we have investigated the growth of spray deposited $\mathrm{Cu}_{2} \mathrm{ZnSnS}_{4}$ (CZTS) thin films on glass substrates at various thiourea concentrations of $(0.14,0.16,0.18,0.20,0.22$ and $0.24) \mathrm{M}$. The structural and optical properties of $\mathrm{Cu}_{2} \mathrm{ZnSnS}_{4}$ (CZTS) thin films deposited by chemical spray pyrolysis (CSP) technique at different thiourea concentrations are reported.

\section{Experimental Procedure}

$\mathrm{Cu}_{2} \mathrm{ZnSnS}_{4}$ (CZTS) thin films were deposited by spray 
pyrolysis (CSP) technique. $\mathrm{Cu}_{2} \mathrm{ZnSnS}_{4}$ (CZTS) thin films are prepared at substrate temperatures $\mathrm{T}_{\mathrm{S}}$ of $(400 \pm 10){ }^{\circ} \mathrm{C}$ keeping the other parameters constant. The precursor solution was obtained by mixing aqueous solutions of $(0.04) \mathrm{mol} / \mathrm{L}$ of copper chloride $(\mathrm{CuCl}),(0.02) \mathrm{mol} / \mathrm{L}$ of Zinc chloride $\left(\mathrm{ZnCl}_{2}\right),(0.02) \mathrm{mol} / \mathrm{L}$ of stannic chloride $\left(\mathrm{SnCl}_{4} .5\left(\mathrm{H}_{2} \mathrm{O}\right)\right)$ and different concentrations $(0.14,0.16,0.18,0.20,0.22$ and $0.24) \mathrm{mol} / \mathrm{L}$ of thiourea $\left(\mathrm{SC}\left(\mathrm{NH}_{2}\right)_{2}\right)$ with a final volume of (100) $\mathrm{mL}$. The resultant solution was sprayed on glass substrates. Other deposition conditions such as spray nozzle substrate distance $(30 \pm 1) \mathrm{cm}$, spray time (15) s, spray interval (2) min and pressure of the carrier gas (1.5) bar were kept constant for each concentration.

The (X-ray) diffraction patterns for the prepared thin films were obtained in a (Shimadzu XRD - 6000) goniometer using copper target $(\mathrm{CuK} \alpha, 1.5418 \AA)$ and Atomic Force Microscopy (AFM) micrographs were recorded by using scanning probe microscope type (SPM-AA3000), contact mode, supplied by Angstrom Advanced Inc. Optical properties in the wavelength range of (300-900) nm were investigated by using UV-VIS-NIR spectroscopy (Shimadzu, UV-1800).

\section{Results and Discussion}

\subsection{Structural Analysis}

Figure (1) illustrates the XRD patterns of the (CZTS) films prepared in this study. It is observed that the XRD patterns for all films show Bragg's angles at $\left(2 \theta \sim 28^{\circ}, 32^{\circ}\right.$, $47^{\circ}$ and $56^{\circ}$ ) which are assigned to (112), (200), (220) and (312) directions respectively. These values are in good agreement with the International Center of Diffraction Data (ICDD) card number (26-0575). The highest intensity peak is at $\left(2 \theta \sim 28^{\circ}\right)$ corresponding to (112) plane. From the results it is concluded that the films have tetragonal polycrystalline structure and this is in agreement with previous studies [6-8].

The full width at half maximum (FWHM) of preferential orientation shows that it has irregular trend with thiourea concentration. The lattice parameter $(a)$ varies within the range of (0.5391-0.5399) $\mathrm{nm}$ and lattice parameter $(c)$ varies within the range of (1.0760-1.0887) $\mathrm{nm}$ as shown in Table (1). These values are in good agreement with theoretical values $(a=0.542 \mathrm{~nm})$ and $(c=1.0848 \mathrm{~nm})[9,10]$.

In Tetragonal ideal structure, the ratio of the lattice vector (c/a) is 2. In the present work two cases are noticed. First, the ratio is less than 2, which implies that the lattice is compressed in the c-axis direction, and second, the ratio is greater than 2 , indicating that the lattice is elongated along the c-axis.

It is important to mention here that there is a very low intensity peak at $\left(2 \theta \approx 46^{\circ}\right)$ which does not belong to the standard (CZTS) phase. This peak is assigned by $(\diamond)$ in figure (1). This diffraction peak may be attributed to $\left(\mathrm{Cu}_{\mathrm{x}} \mathrm{S}\right)$ phase as reported by previous studies [11-13]. The possible reason behind the appearance of this secondary phase is the high concentration of thiourea in the sprayed solution. When the concentration of sulphur, which is electronegative element, increases in the starting solution, it may instantaneously react with metal ions available to form secondary phases [12]. Moreover, the broad peak at $\left(2 \theta \approx 25^{\circ}\right)$ can be attributed to the glass material of the substrate.

The average crystallite size and microstrain of the prepared films can be estimated using Williamson-Hall (W-H) analysis which depends on the following equation [14]:

$$
\beta_{\mathrm{hkl}} \cos \theta=\mathrm{k} \lambda / \mathrm{D}+4 \mathrm{~S} \sin \theta
$$

Where $\beta_{\mathrm{hkl}}$ is (FWHM) of all peaks, D is the average crystallite size, $\mathrm{k}$ is constant $=0.9, \lambda$ is wavelength of the XRD diffractometer, $\theta$ is the Bragg's angle for the corresponding peaks, and $\mathrm{S}$ is the microstrain. The strain and the crystallite size can be estimated by plotting $\beta_{\mathrm{hkl}} \cos \theta$ versus $4 \sin \theta$ where the slope and $y$-intercept of the fitted line give the values of crystallite size and strain respectively as it is clear in Figure-2.

The crystallite size of all films is also calculated for (112) direction by Scherrer's formula [15]:

$$
\mathrm{D}=\mathrm{K} \lambda / \beta \cos \theta
$$

The average crystallite size (D) calculated by this equation has maximum value of (31.25) $\mathrm{nm}$ at thiourea concentration of (0.20) M, and it was minimum (18.02) nm for the $\mathrm{Cu}_{2} \mathrm{ZnSnS}_{4}$ (CZTS) thin film prepared at thiourea concentration of (0.16) M, as shown in Figure-3 and this result is in agreement with previous studies $[12,16]$. It is reported that when the thiourea concentration increases, the mobility of the atoms located on the surface increases, so these atoms can rearrange their positions to occupy more stable sites. This process controls the favorite growth orientation of the crystal structure. All values of microstrain were negative which indicates the occurrence of compression in the lattice, as shown in Table-1. The microstrains are induced during the growth of thin films, and will be raised from stretching or compression in the lattice [17].

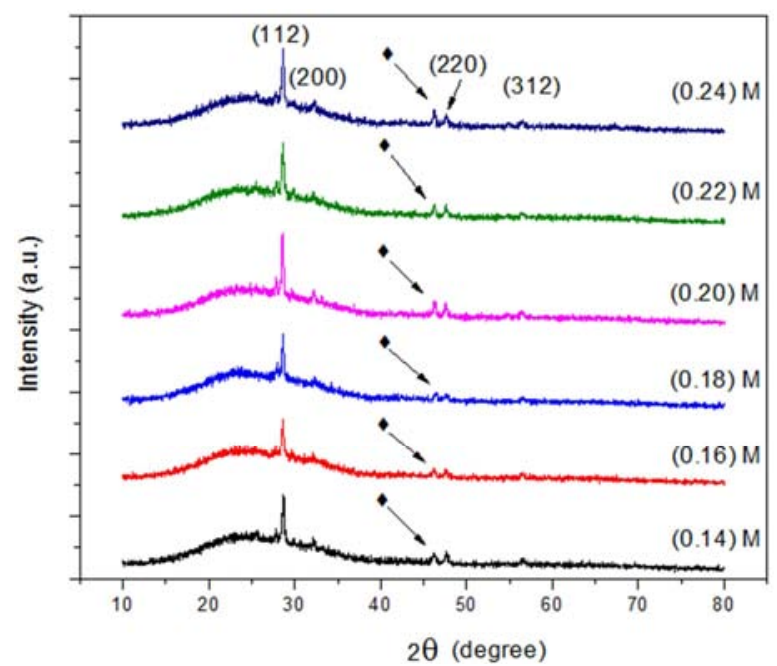

Fig. 1. X-Ray diffraction patterns of (CZTS) thin films. 
Table 1. Structural parameters of (CZTS) thin films.

\begin{tabular}{lllllll}
\hline Thiourea Concentration (M) & $\mathbf{0 . 1 4}$ & $\mathbf{0 . 1 6}$ & $\mathbf{0 . 1 8}$ & $\mathbf{0 . 2 0}$ & $\mathbf{0 . 2 2}$ & $\mathbf{0 . 2 4}$ \\
\hline 2 $\theta(\mathrm{deg})$ & 28.7025 & 28.6409 & 28.6507 & 28.6312 & 28.6553 & 28.6653 \\
(FWHM) (rad) & 0.00579 & 0.00793 & 0.00667 & 0.00457 & 0.00557 & 0.00562 \\
Dav $(\mathrm{nm})$ by Scherrer & 24.68 & 18.02 & 21.43 & 31.25 & 25.67 & 25.42 \\
Dav $(\mathrm{nm})$ by W- Hall & 22.47 & 15.10 & 15.07 & 25.67 & 21.66 & 20.09 \\
$\mathrm{a}=\mathrm{b}(\mathrm{nm})$ & 0.5391 & 0.5399 & 0.5393 & 0.5399 & 0.5397 & 0.5395 \\
$\mathrm{c}(\mathrm{nm})$ & 1.0828 & 1.0820 & 1.0820 & 1.0776 & 1.0760 & 1.0887 \\
The ratio $(\mathrm{c} / \mathrm{a})$ & 2.008 & 2.004 & 2.006 & 1.995 & 1.995 & 2.018 \\
$\mathrm{~T}_{\mathrm{C}}$ & 1.238 & 1.197 & 1.072 & 1.086 & 1.149 & 1.084 \\
$\delta\left(\mathrm{m}^{-2}\right) * 10^{15}$ by Scherrer & 1.64 & 3.07 & 2.17 & 1.02 & 1.51 & 1.54 \\
$\mathrm{~N}_{\mathrm{o}}\left(\mathrm{m}^{-2}\right)^{*} 10^{16}$ by Scherrer & 2.02 & 5.25 & 3.10 & 1.00 & 1.81 & 2.05 \\
$\delta\left(\mathrm{m}^{-2}\right)^{-1} 10^{15}$ by W- Hall & 1.98 & 4.38 & 4.40 & 1.51 & 2.13 & 2.47 \\
$\mathrm{~N}_{\mathrm{o}}\left(\mathrm{m}^{-2}\right) * 10^{16}$ by W- Hall & 2.68 & 8.93 & 8.91 & 1.80 & 3.02 & 4.21 \\
Microstrain $(\mathrm{S})$ & -0.00015 & -0.00247 & -0.00124 & -0.00044 & -0.00073 & -0.00078 \\
\hline
\end{tabular}
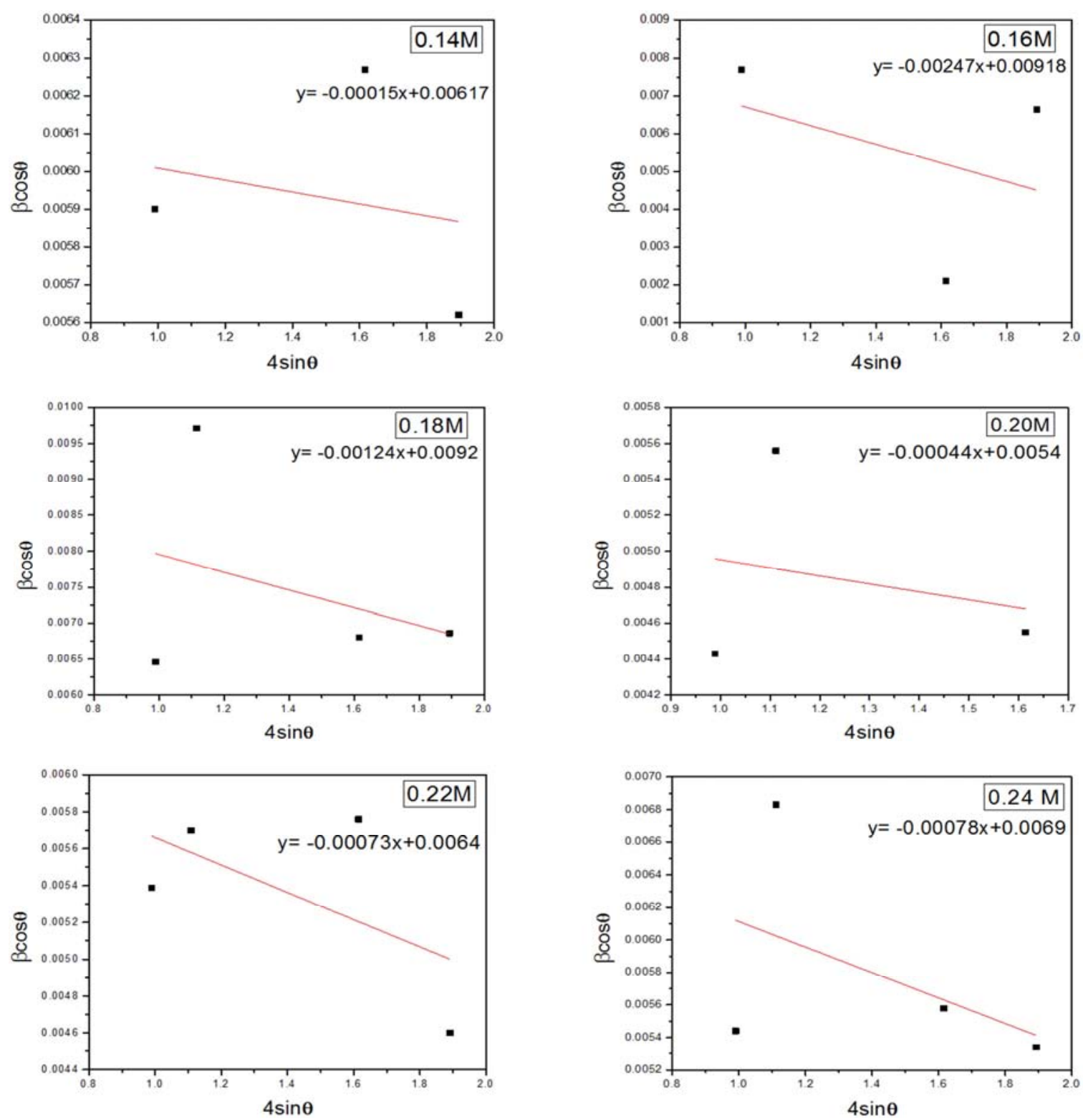

Fig. 2. The $W$-H analysis of (CZTS) thin films.

The texture coefficient (Tc) gives a numerical representation of texture of planes in the crystal. If its value is greater than 1 then it means that there are numerous of grains in that direction. The texture coefficients Tc (hkl) can be calculated using the following equation [15]: 


$$
\mathrm{T}_{\mathrm{c}}(\mathrm{hk} l)=\frac{\mathrm{I}(\mathrm{hk} l) / \mathrm{I}_{\mathrm{o}}(\mathrm{hk} l)}{\mathrm{N}_{\mathrm{r}}^{-1} \sum \mathrm{I}(\mathrm{hk} l) / \mathrm{I}_{\mathrm{o}}(\mathrm{hk} l)}
$$

Where I (hkl) is the measured intensity, Io (hkl) taken from the ICDD standard data, $(\mathrm{N})$ is the number of peaks and (hkl) are Miller indices. The texture coefficient is calculated for crystal plane (112) of the $\mathrm{Cu}_{2} \mathrm{ZnSnS}_{4}$ (CZTS) films. All values of texture coefficient were greater than 1 as shown in Table (1) which indicate the abundance of grains in the (112) direction.

\section{2. (AFM) Results}

The 3D AFM micrographs of the $\mathrm{Cu}_{2} \mathrm{ZnSnS}_{4}$ (CZTS) thin films are shown in Figure-4. The size of the scanned area was $(2 \times 2) \mu \mathrm{m}^{2}$. AFM results show homogenous and smooth thin films. The average grain size, average roughness and root mean square (RMS) roughness for all samples estimated from AFM are given in Table-2.

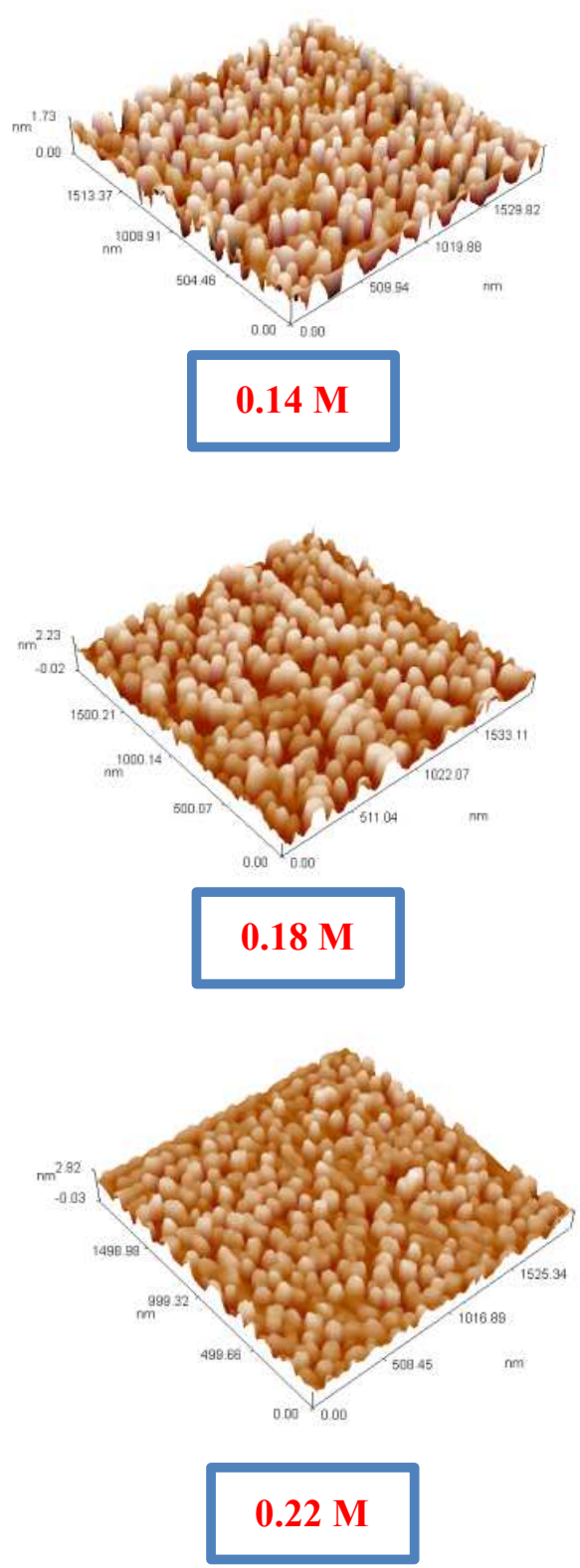

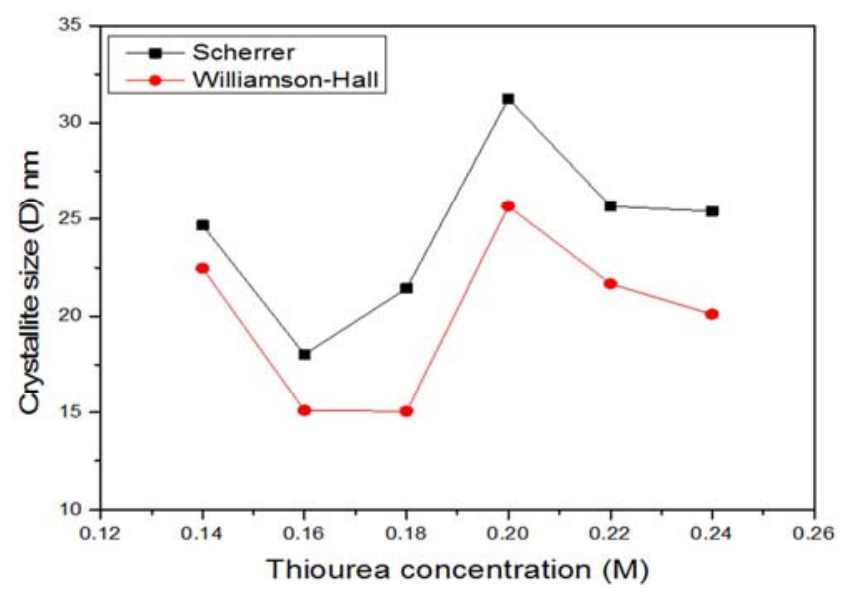

Fig. 3. The crystallite size of (CZTS) thin films at different thiourea concentrations calculated by Scherrer's formula and $(W-H)$ method.
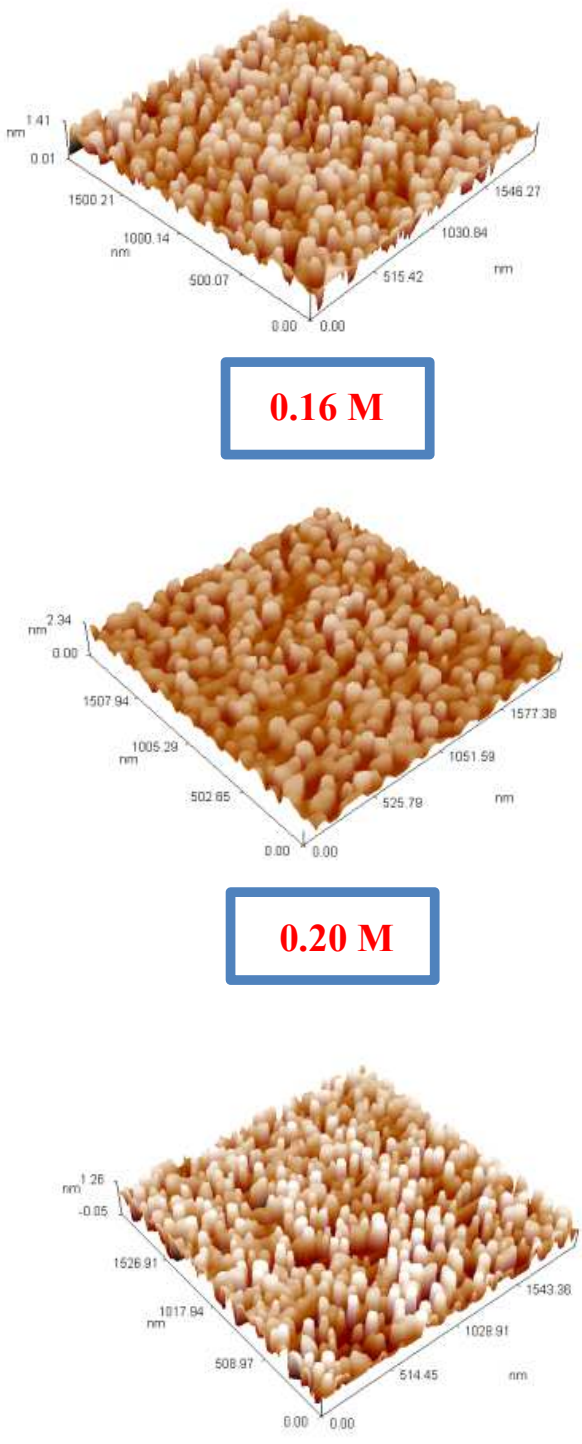

$0.24 \mathrm{M}$

Fig. 4. (3-D) AFM images of (CZTS) thin films at different thiourea concentrations. 
Table 2. The surface roughness, RMS and grain size of (CZTS) thin films.

\begin{tabular}{llll}
\hline $\begin{array}{l}\text { Thiourea } \\
\text { Concentration (M) }\end{array}$ & $\begin{array}{l}\text { Surface } \\
\text { Roughness (nm) }\end{array}$ & RMS (nm) & $\begin{array}{l}\text { Grain Size } \\
\text { (nm) }\end{array}$ \\
\hline 0.14 & 0.397 & 0.464 & 78.53 \\
0.16 & 0.260 & 0.303 & 83.20 \\
0.18 & 0.383 & 0.434 & 92.64 \\
0.20 & 0.312 & 0.360 & 86.43 \\
0.22 & 0.339 & 0.402 & 82.92 \\
0.24 & 0.311 & 0.361 & 70.90 \\
\hline
\end{tabular}

\subsection{Optical Properties}

Optical absorption spectra of the films in spectral range of (300-900) nm were recorded by using (UV-visible spectrophotometer). The analysis of the dependence of absorption coefficient on photon energy in the high absorption regions is performed to obtain the detailed information about the energy band gaps of the films. Figure (5) shows the relation between transmittance and wavelength for $\mathrm{Cu}_{2} \mathrm{ZnSnS}_{4}$ (CZTS) thin films. It can be noticed that the transmittance for all thin films increases rapidly as the wavelength $(\lambda)$ increases in the range of (320-700) $\mathrm{nm}$, and then increases slowly at higher wavelengths. The thin films were found to be highly transmittance in the visible wavelength region and near IR region of the electromagnetic spectrum with transmittance value of about $(88 \%)$ recorded at $(\lambda>850 \mathrm{~nm})$ with thiourea concentration of $(0.14) \mathrm{M}$, therefore more attention has been paid to study this type of films for using in solar cells.

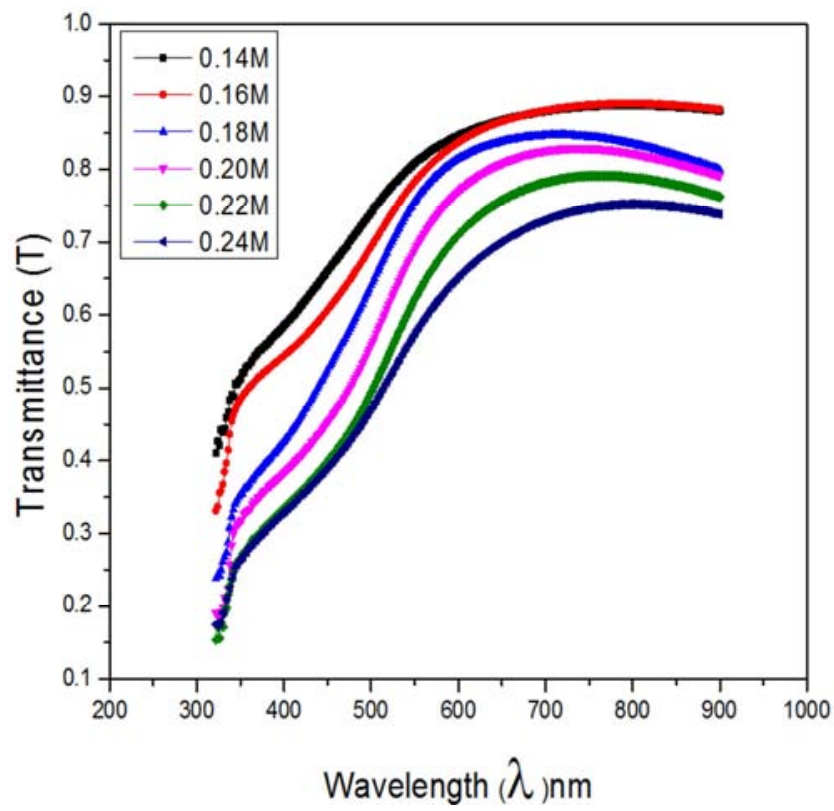

Fig. 5. Transmittance versus wavelength of (CZTS) thin films.

Figure (6) shows the optical absorbance as a function of wavelength $(\lambda)$ of $\mathrm{Cu}_{2} \mathrm{ZnSnS}_{4}$ (CZTS) thin films. The absorbance decreases rapidly at short wavelengths corresponding to the energy gap of the film.

This evident increase of energy is due to the interaction of the material electrons with the incident photons which have enough energy for the occurrence of electron transitions. The absorbance has an increasing trend as thiourea concentration increases. By using the well-known formula, the absorption coefficient $(\alpha)$ can be calculated for $\mathrm{Cu}_{2} \mathrm{ZnSnS}_{4}$ (CZTS) thin films [18]:

$$
\alpha=2.303 \mathrm{~A} / \mathrm{t}
$$

Where (A) is the absorbance and $(\mathrm{t})$ is the film thickness. Figure (7) shows the absorption coefficient of $\mathrm{Cu}_{2} \mathrm{ZnSnS}_{4}$ (CZTS) thin films as a function of photon energy in the range of (1.38 - 3.92) eV before and after annealing. The values of absorption coefficient is higher than $\left(\alpha>10^{4}\right) \mathrm{cm}^{-1}$ which indicates the increase of the probability of the occurrence of direct transitions. It have been noticed that all the prepared thin films have high absorption coefficient between $10^{4}$ and $10^{5} \mathrm{~cm}^{-1}$ in visible range and the near-IR spectral range which is in agreement with other reports $[10,16]$. The absorption coefficient increases with increasing thiourea concentration from (0.14 to 0.24$) \mathrm{M}$.

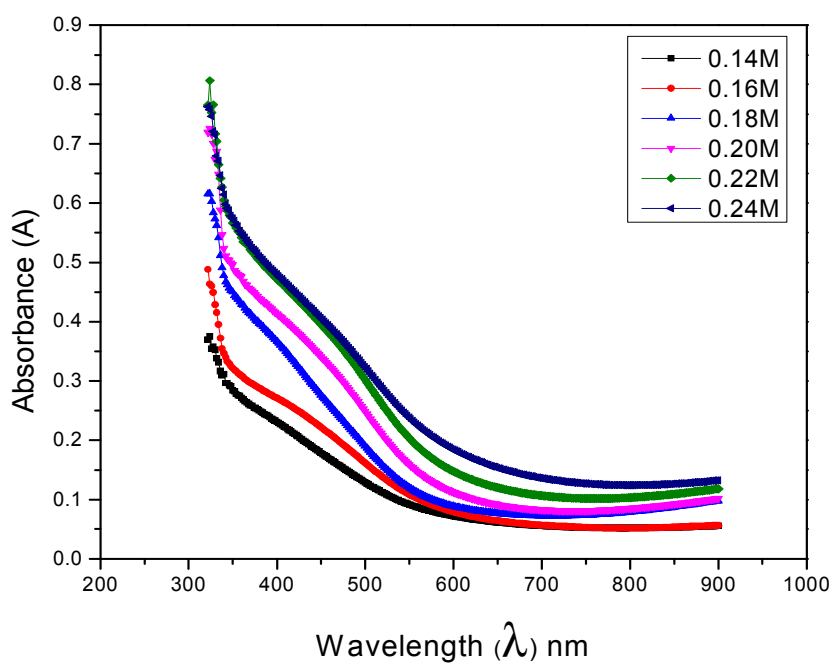

Fig. 6. Absorbance versus wavelength of (CZTS) thin films.

The optical energy gap $\left(E_{g}\right)$ is given by the well known relation [19]:

$$
\alpha h v=A^{\prime}\left(\mathrm{h} v-\mathrm{E}_{\mathrm{g}}{ }^{\mathrm{opt}}\right)^{\mathrm{r}}
$$

Where $\left(E_{g}\right)$ the optical energy gap of the film, $(B)$ is is a constant, $(\mathrm{h} v)$ is the incident photon energy and $\mathrm{r}$ is a numeric value equal to $(1 / 2)$ for allowed direct transition, 2 for allowed indirect transition, 3 for forbidden direct transition and $(3 / 2)$ for forbidden indirect transition. 


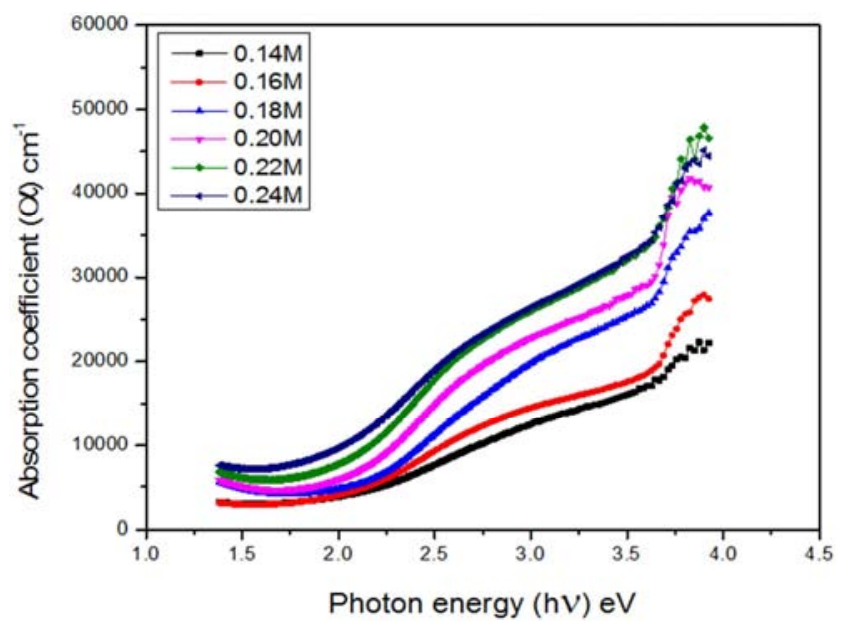

Fig. 7. Absorption coefficient versus photon energy of (CZTS) thin films.

The optical band gap can be estimated by Tauc's model as shown in figure (8) where a graph of $(\alpha h v)^{2}$ versus (hv) is plotted and the extrapolation of the linear portion of the
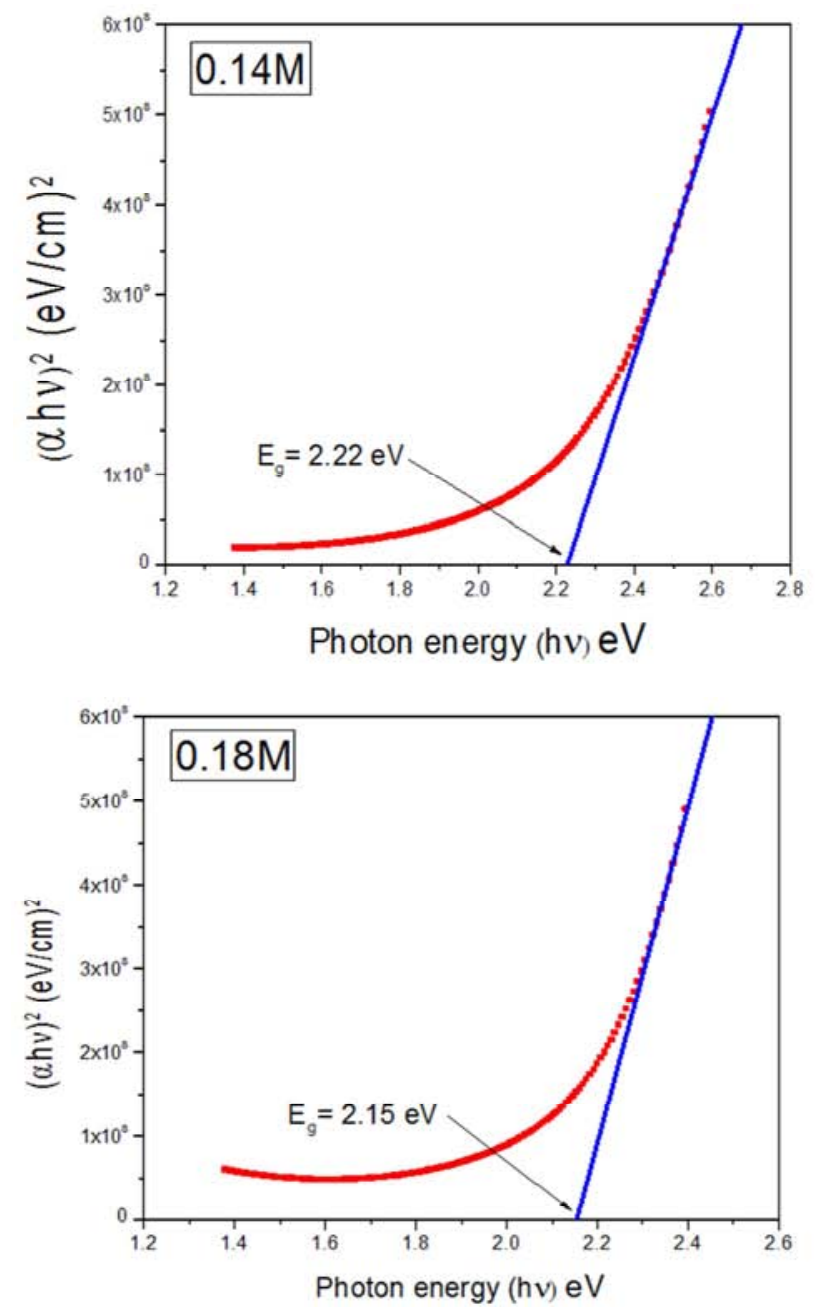

graph gives the value of the direct optical band gap of the deposited films [20]. It is clear that the optical band gap has a decreasing trend as the thiourea concentration increases, which is in agreement with other reports [12, 16]. The deposited thin film at a thiourea concentration of $(0.24 \mathrm{M})$ is suitable as absorber layer in solar cells [16]. Table (3) summarized the energy gap values obtained in this study.

Urbach energy may be used as an indication for the quality of the material and it can be calculated using the following formula [18]:

$$
\alpha=\alpha_{\mathrm{o}} \exp \left(\mathrm{h} v / \mathrm{E}_{\mathrm{u}}\right)
$$

Where Eu represents Urbach energy and $\alpha_{\mathrm{o}}$ is constant. It is observed that the urbach energy of the thin films is minimum $(\sim 469) \mathrm{meV}$ for the film prepared at $(0.18) \mathrm{M}$ as shown in Figure (9). This can be attributed to the improvement of the crystal structure of the deposited thin films which leads to the decrease in the density of the localized states [21]. The obtained $\mathrm{E}_{\mathrm{U}}$ values are given in Table (4).
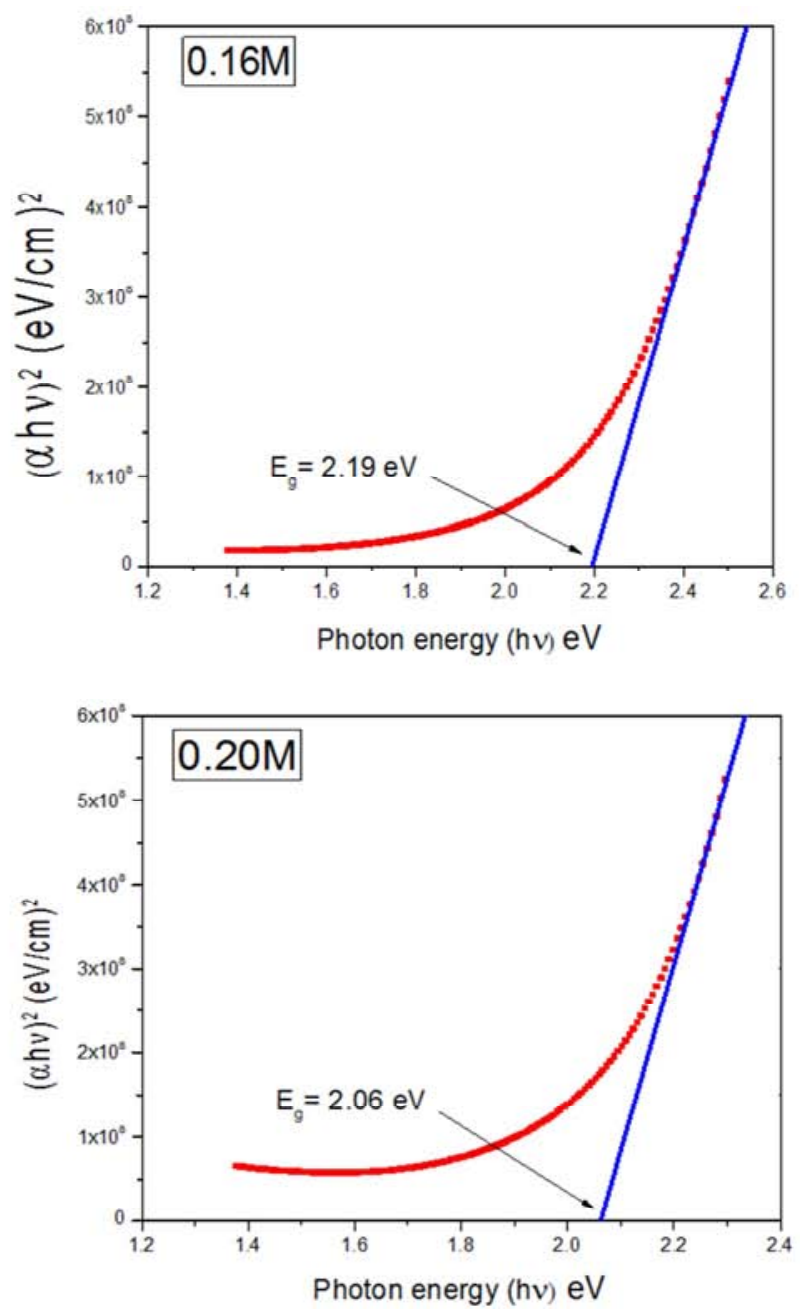

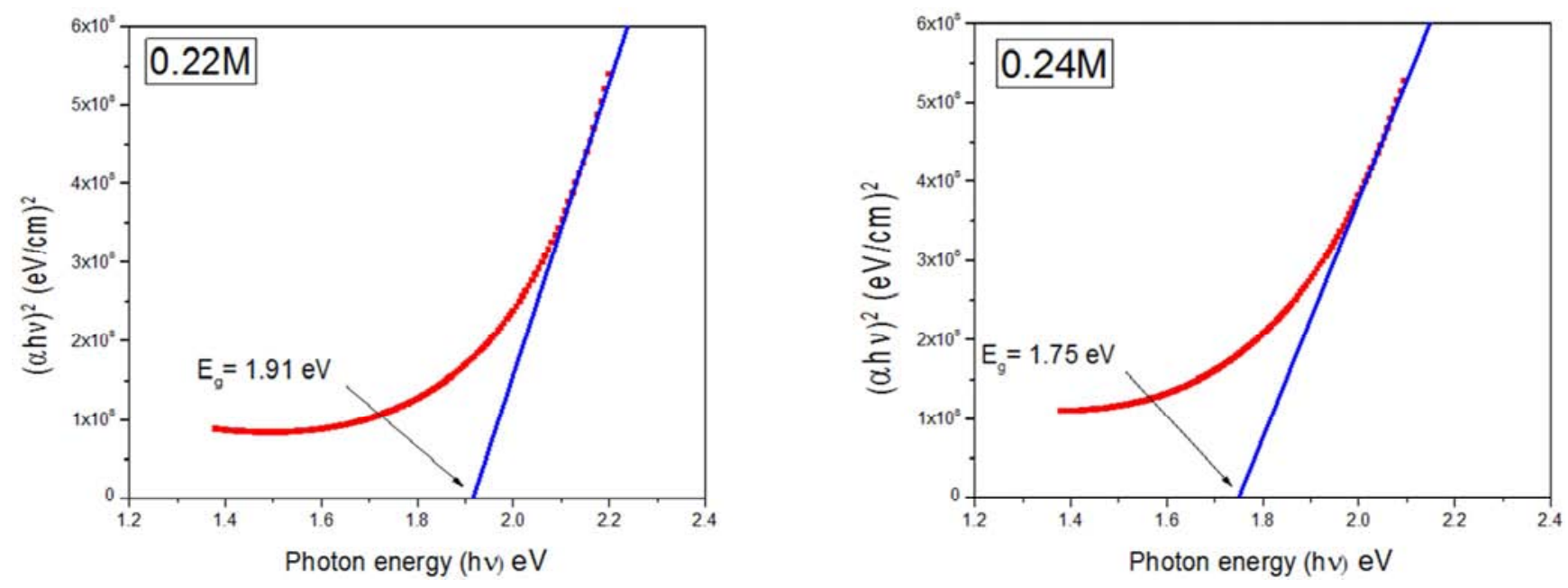

Fig. 8. Tauc's plots of (CZTS) thin films.
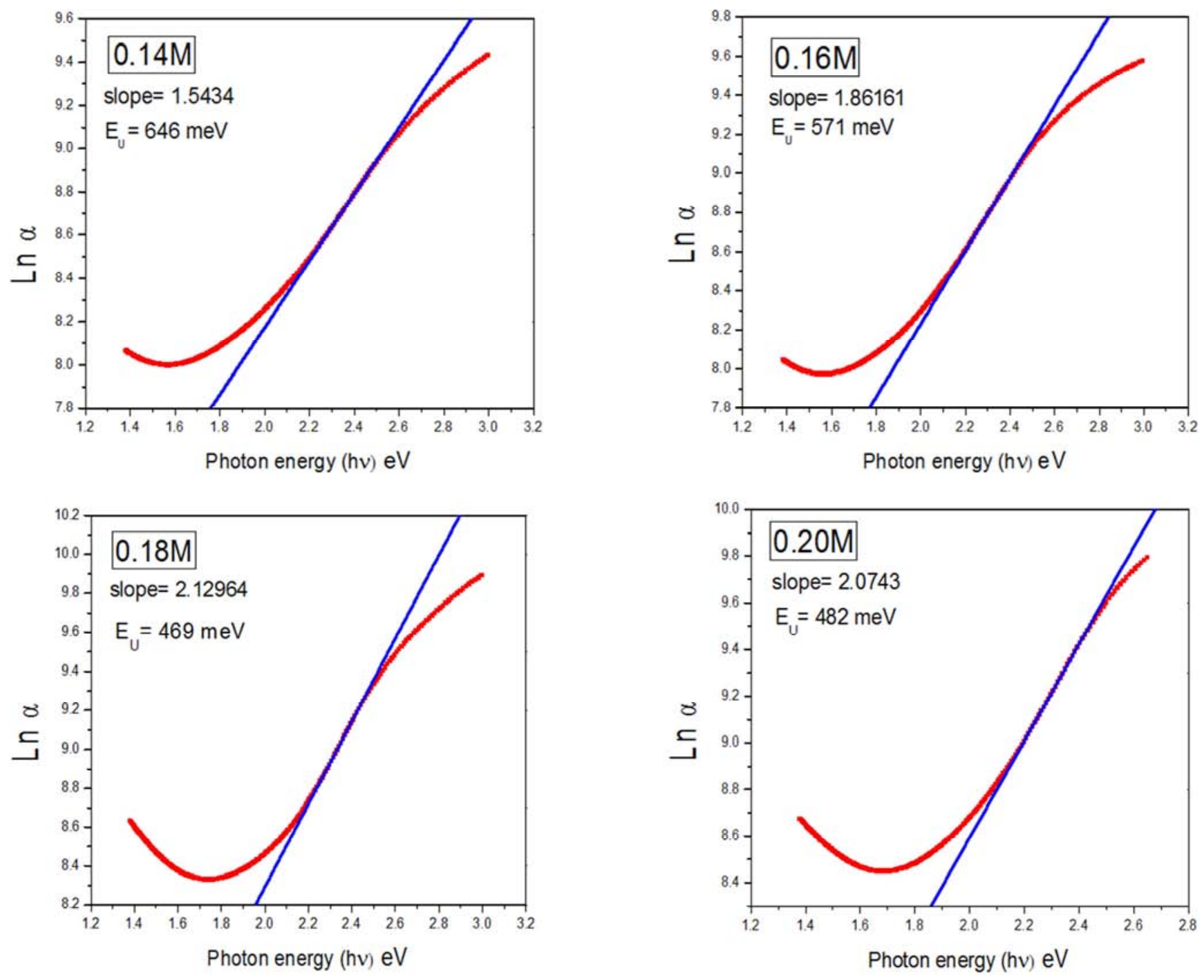

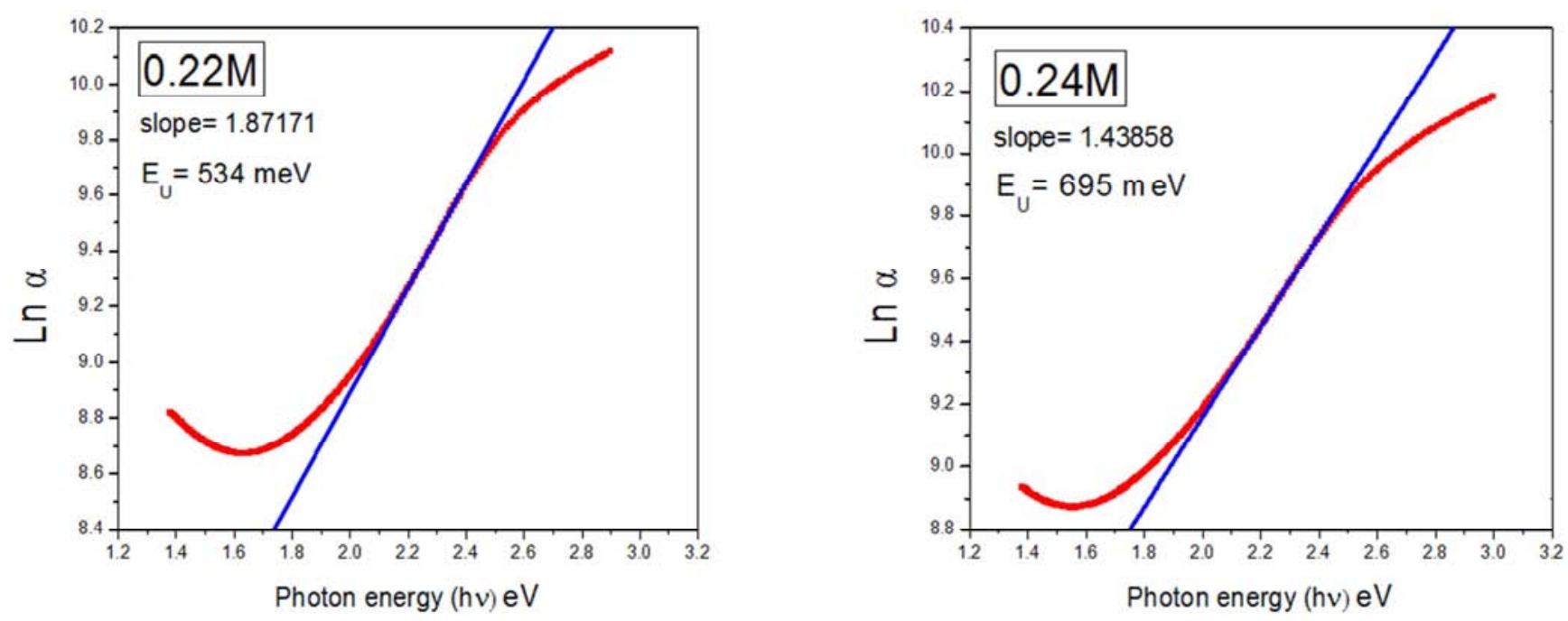

Fig. 9. Urbach plots of (CZTS) thin films.

Table 3. Values of optical energy gap of (CZTS) thin films.

\begin{tabular}{ll}
\hline Thiourea Concentration $(\mathbf{M})$ & $\mathbf{E}_{\mathrm{g}}(\mathbf{e V})$ \\
\hline 0.14 & 2.22 \\
0.16 & 2.19 \\
0.18 & 2.15 \\
0.20 & 2.06 \\
0.22 & 1.91 \\
0.24 & 1.75 \\
\hline
\end{tabular}

Table 4. Values of Urbach Energies of (CZTS) thin films.

\begin{tabular}{ll}
\hline Thiourea Concentration $(\mathbf{M})$ & Eu $(\mathbf{m e V})$ \\
\hline 0.14 & 646 \\
0.16 & 571 \\
0.18 & 469 \\
0.20 & 482 \\
0.22 & 534 \\
0.24 & 695 \\
\hline
\end{tabular}

The refractive index (n) can be determined from the reflectance $(\mathrm{R})$ by using the relation [22]:

$$
n=\left[\frac{(1+R)^{2}}{(1-R)^{2}}-\left(k_{o}^{2}-1\right)\right]^{1 / 2}+\frac{(1+R)}{(1-R)}
$$

Where $k_{o}$ is the extinction coefficient. The relation between refractive index (n) and wavelength for spectrum range (300-900) nm of $\mathrm{Cu}_{2} \mathrm{ZnSnS}_{4}$ (CZTS) thin films at different thiourea concentrations is shown in figure (10). It can be seen that the refractive index (n) increases with increasing thiourea concentration. This increase can be attributed to the film densification and improvement in the crystallinity of the films. This result is in agreement with other reports [23].

The extinction coefficient $\left(\mathrm{k}_{\mathrm{o}}\right)$ can be determined by using the relation [24-26]:

$$
\mathrm{K}_{\mathrm{o}}=\alpha \lambda / 4 \pi
$$

The extinction coefficient $\left(\mathrm{k}_{\mathrm{o}}\right)$ decreases rapidly at short wavelengths (322-650) $\mathrm{nm}$ and after that the values of extinction coefficient $\left(\mathrm{k}_{\mathrm{o}}\right)$ increase slowly. The high and fall in the value of extinction coefficient $\left(\mathrm{k}_{\mathrm{o}}\right)$ is directly linked to the absorption of light. Figure (11) shows the extinction coefficient $\left(\mathrm{k}_{\mathrm{o}}\right)$ versus wavelength for all samples. The results shows that the extinction coefficient $\left(\mathrm{k}_{\mathrm{o}}\right)$ of the prepared thin films has values in the range of (0.054- 0.112). The complex dielectric constant $(\varepsilon)$ can be represented by the following equation $[27,28]$ :

$$
\varepsilon=\varepsilon_{\mathrm{r}}+\mathrm{i} \varepsilon_{\mathrm{i}}
$$

Where $\varepsilon_{\mathrm{r}}$ is the real part of dielectric constant and $\varepsilon_{\mathrm{i}}$ is the imaginary part of dielectric constant. The dielectric constant in its two parts is given by the following equations [29]:

$$
\begin{gathered}
\varepsilon_{\mathrm{r}}=\mathrm{n}_{\circ}^{2}-\mathrm{k}_{\circ}^{2} \\
\varepsilon_{\mathrm{i}}=2 \mathrm{n} \circ \mathrm{k} 。
\end{gathered}
$$

The variation of the real and imaginary parts of dielectric constant with respect to photon energy for (CZTS) thin films are show in figures (12) and (13) respectively. It can be seen that the Real and imaginary parts of dielectric constant increase with increasing thiourea concentration.

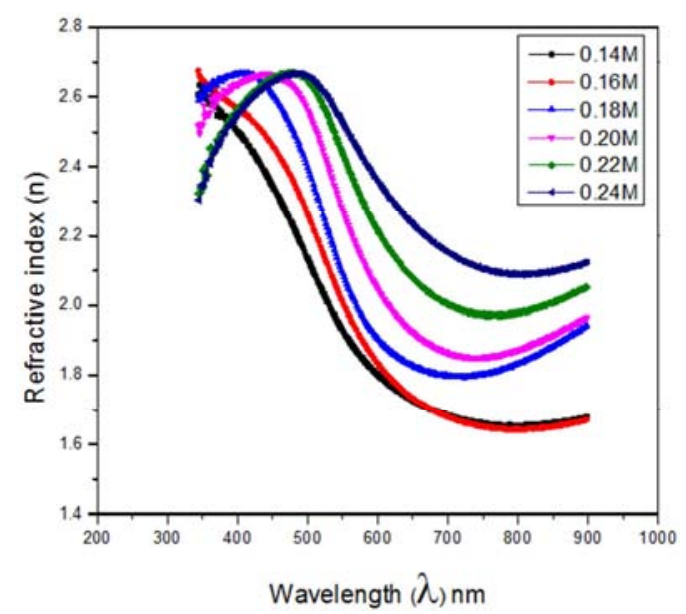

Fig. 10. Refractive index versus wavelength of CZTS) thin films. 


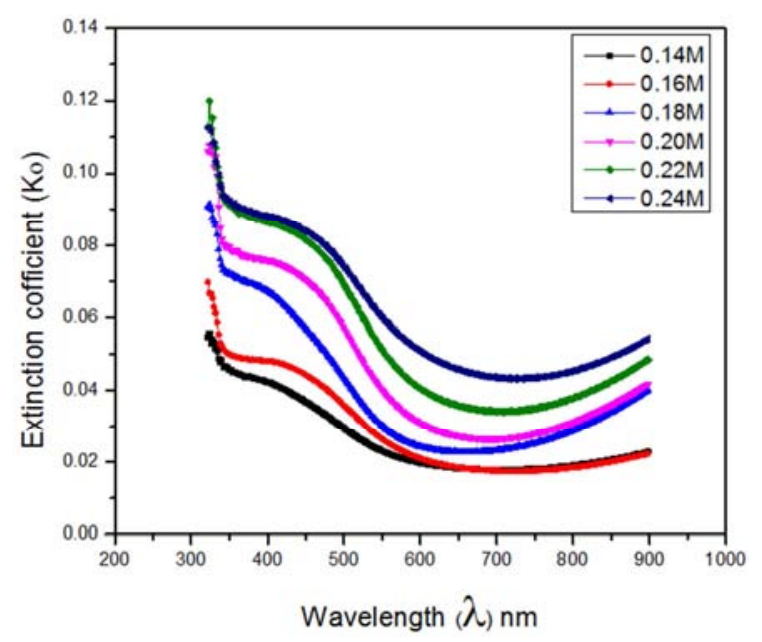

Fig. 11. Extinction coefficient versus wavelength of (CZTS) thin films.

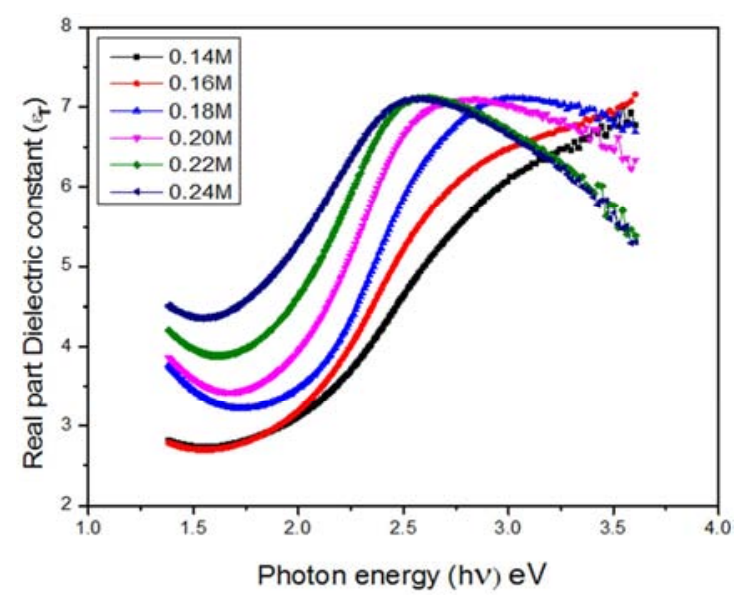

Fig. 12. Real part of dielectric constant versus photon energy of (CZTS) thin films.

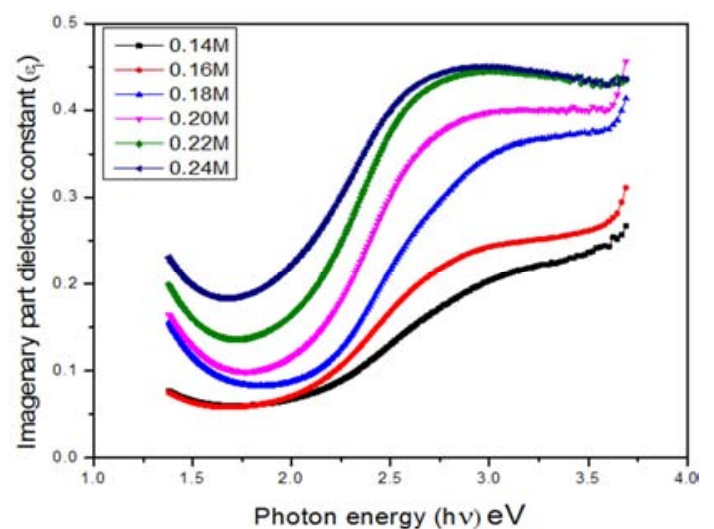

Fig. 13. Imaginary part of dielectric constant versus photon energy of (CZTS) thin films.

\subsection{Conclusions}

(CZTS) thin films were deposited on glass substrates by chemical spray pyrolysis technique successfully. The XRD results showed that the prepared films are polycrystalline having tetragonal structure. The main most significant peaks are corresponding to the (112), (200), (220) and (312) planes. The average crystallite size (D) of the thin films is estimated for (112) direction by Scherrer's formula and it is found that the (CZTS) thin films have maximum crystallite size (D) of (31.25) nm at thiourea concentration of $(0.20) \mathrm{M}$, and it was minimum (18.02) $\mathrm{nm}$ for the $\mathrm{Cu}_{2} \mathrm{ZnSnS}_{4}$ (CZTS) thin film prepared at thiourea concentration of $(0.16) \mathrm{M}$. The (AFM) micrographs showed that the films are homogenous and smooth according to the low values of surface roughness and RMS obtained. The allowed direct optical band gap values range between (2.22 and 1.75$) \mathrm{eV}$, decreasing when the thiourea concentration increases suggesting that the deposited films are good candidates as absorber layer in solar cells.

\section{References}

[1] H. Katagiri, N. Ishigaki, T. Ishida and K. Saito, "Characterization of $\mathrm{Cu}_{2} \mathrm{ZnSnS}_{4}$ Thin Films Prepared by Vapor Phase Sulfurization" Jpn. J. Appl. Phys. Vol. 40, No. 2A, pp. 500-504, (2001).

[2] X. Zhang, X. Shi, W. Ye, C. Ma, C. Wang, " Electrochemical deposition of quaternary $\mathrm{Cu}_{2} \mathrm{ZnSnS}_{4}$ thin films as potential solar cell material" Materials Science and Processing, Vol. 94, pp. 381-386, (2009).

[3] T. K. Todorov, J. Tang, S. Bag, O. Gunawan, T. Gokmen, Y. Zhu and D. B. Mitzi, "Beyond 11\% efficiency: characteristics of state-of-the-art $\mathrm{Cu}_{2} \mathrm{ZnSn}(\mathrm{S}, \mathrm{Se})_{4}$ solar cells", Advanced Energy Materials, Vol. 1, no. 3, pp. 34-38, (2013).

[4] Pramod S. Patil, "Versatility of chemical spray pyrolysis technique" Materials Chemistry and Physics, Vol. 59, Issue 3, pp. 185-19, (1999).

[5] N. Nakayama and K. Ito, "Sprayed films of stannite $\mathrm{Cu}_{2} \mathrm{ZnSnS}_{4}$ " Applied Surface Science, Vol. 92, pp. 171-175, (1996).

[6] M. Valdes, G. Santoro and M. Vazquez, "Spray deposition of $\mathrm{Cu}_{2} \mathrm{ZnSnS}_{4}$ thin films", Journal of Alloys and Compounds, Vol. 585, pp. 776-782, (2014).

[7] R. J. Deokate, A. D. Adsool, N. S. Shinde, S. M. Pawar and C. D. Lokhande, "Structural and Optical properties spraydeposited $\mathrm{Cu}_{2} \mathrm{ZnSnS}_{4}$ thin films", Energy procedia, Vol. 54, pp. 627-633, (2014).

[8] E. P. Subramania, G. Rajesh, N. Muthukumarasamy, M. Thambidurai, V. Asokan and D. Velauthapillai, "Solar cells of $\mathrm{Cu}_{2} \mathrm{ZnSnS}_{4}$ thin films prepared by chemical bath deposition method", Indian Journal of Pure \& Applied Physics, Vol. 52, pp. 620-624, (2014).

[9] Y. B. Kishore Kumar, G. Suresh Babu, P. Uday Bhaskar and V. Sundara Raja R. Touati, M. Ben Rabeh, M. Kanzari, "Preparation and characterization of spray-deposited $\mathrm{Cu}_{2} \mathrm{ZnSnS}_{4}$ thin films", Solar Energy Materials \& Solar Cells, Vol. 93, pp. 1230-1237, (2009).

[10] A. U. Sheleg, V. G. Hurtavy, A. V. Mudryi, M. Ya. Valakh, V. O. Yukhymchuk, I. S. Babichuk, M. Leon and R. Caballero, "Determination of the Structural and Optical Characteristics of $\mathrm{Cu}_{2} \mathrm{ZnSnS}_{4}$ Semiconductor Thin Films", Semiconductors, Vol. 48, No. 10, pp. 1296-1302, (2014).

[11] R. Touati, M. Ben Rabeh and M. Kanzari, "Effect of postsulfurization on the structural and optical properties of $\mathrm{Cu}_{2} \mathrm{ZnSnS}_{4}$ thin films deposited by vacuum evaporation method", Thin Solid Films, TSF-33996, No. 5, pp. 1-5, (2015). 
[12] Y. B. Kishore Kumar, P. Uday Bhaskar, G. Suresh Babu and V. Sundara Raja, "Effect of copper salt and thiourea concentrations on the formation of $\mathrm{Cu}_{2} \mathrm{ZnSnS}_{4}$ thin films by spray pyrolysis", Phys. Status Solidi A 207, No. 1, pp. 149$156,(2010)$.

[13] M. Adelifard and R. Torkamani, "Spray deposited $\mathrm{Cu}_{2} \mathrm{ZnSnS}_{4}$ nanostructured absorber layer: a promising candidate for solar cell applications", Journal of Materials Science: Materials in Electronics, DOI. 10.1007/s10854-015-2888-4, (2015).

[14] V. D. Mote, Y Purushotham and BN Dole, "WilliamsonHallAnalysis in estimation of lattice strain in nanometer-sized $\mathrm{ZnO}$ particles", Journal of Theoretical and Applied Physics, Vol. 6, pp. 1-8, (2012).

[15] C. Barret, T. B. Massalki, "Structure of Metals", Oxford Pergamon, (1980).

[16] Nabeel A. Bakr, Ziad T. Khodair and Shahlaa M. Abdul Hassan, "Effect of Substrate Temperature on Structural and Optical Properties of $\mathrm{Cu}_{2} \mathrm{ZnSnS}_{4}$ (CZTS) Films Prepared by Chemical Spray Pyrolysis Method", Research Journal of Chemical Sciences, Vol. 5, Issue 10, pp. 51-61, October, (2014).

[17] Arwaa Fadil Saleh, "Structural and morphological studies of $\mathrm{NiO}$ thin films prepared by Rapid thermal oxidation method", International Journal of Application or Innovation in Engineering \&Management (IJAIEM) Vol. 2 (1), p. 16, (2013).

[18] Bakr N. A., El-Hadidy H., Hammam M. and Migahed M. D., "Refractive index, extinction coefficient and DC conductivity of amorphous arsenic triselenide thin film doped with silver", Thin Solid Films, Vol. 424, pp. 296-302, (2003).

[19] J. Tauc, Amorphous and Liquid Semiconductors, Plenum, London, (1974).

[20] Solanki G. K., Gosai N. N. and Patel K. D., "Structural, Optical and Dielectric Properties of Tin Selenide Nanoparticles Prepared by Aqueous Solution Method", Res. J. chem. sci., Vol. 5 (3), pp. 1-5, (2015).
[21] Shadia Jamil Ikhmayies and Riyad N. Ahmad-Bitar, "A study of the optical band gap energy and Urbach tail of spraydeposited CdS: In thin films", Journal of Materials research technology, Vol. 2, No. 3, pp. 221-227, (2013).

[22] B. A. Ezekoye and C. E. Okeke, "Optical Properties in PbHgS Ternary Thin Films Deposited by Solution Growth Method", Pacific Journal of Science and Technology, Vol. 7 (2), pp. 108113, (2006).

[23] Bakr N. A., "Characterization of a CdZnTe/CdTe hetero structure system prepared by $\mathrm{Zn}$ diffusion into aCdTe thin film", J. Cryst. Growth, Vol. 235 (1), pp. 217-223, (2002).

[24] Balu A. R., Nagarethinam V. S., Arunkumar N. and Suganya M., "Nanocrystalline $\mathrm{NiO}$ thin films prepared by a low cost simplified spray technique using perfume atomizer", J. Electron Devices, Vol. 13, pp. 920-930, (2012).

[25] Ahmed S. S., Hassan E. K. and G. H. Mohamed, "Investigation of Optical Proper-ties of $\mathrm{NiO}_{0.99} \mathrm{Cu}_{0.01}$ Thin Film by Thermal Evaporation Technique", Int. J. Adv. Res., Vol. 2 (2), pp. 633-638, (2014).

[26] S. Abdullahi, A. U. Moreh, B. Hamza, U. Sadiya, Z. Abdullahi, M. A. Wara, H. Kamaluddeen, M. A. Kebbe, and U. F. Monsurat, "Optical Characterization of Fluorine doped Tin Oxide (FTO) thin films deposited by spray pyrolysis technique and annealed under Nitrogen atmosphere", International Journal of Innovation and Applied Studies, Vol. 9 (2), pp. 947-955, (2014).

[27] Ezenwa I. A., "Optical Analysis of Chemical bath Fabricated $\mathrm{CuO}$ Thin Films", Res. J. Recent Sci., Vol. 1 (1), pp. 46-50, (2012).

[28] Mattes B. L. and Kazmarsk. L., "Polycrystalline and Amorphous Thin Films and Devices", $2^{\text {nd }}$ Ed, Academic Press, (1980).

[29] Okereke N. A. and Ekpunobi A. J., "XRD and UV-VIS-IR Studies of Chemically-Synthesized Copper Selenide Thin Films", Res. J. chem. sci., Vol. 1 (6), pp. 64-70, (2011). 